\title{
KERANGKA KEBIJAKAN DAN REFORMASI HUKUM UNTUK KELANCARAN PERDAGANGAN SECARA ELEKTRONIK (E-COMMERCE) DI INDONESIA
}

\author{
Edmon Makarim ${ }^{1}$
}

\begin{abstract}
There is confusion when trying to draw a strict distinction between ecommerce to e-business. To synergize the validity of UU-ITE with Trade Act, then it seems we need a definition of an intermediary who is expected to make a link point to provide an understanding of the Electronic Commerce Business Activities that will encompass all types and forms of Commerce to do business with Electronic Communication, so as to conclude that electronic commerce is able to provide legal protection to the use or consumers. Based on the above reasoning, then there needs to be coordination between the agencies authority manager and supervisor of the network of communication and information technology with the agency manager and supervisor of the marketing trade, the Ministry of Commerce.
\end{abstract}

Keywords: e-commerce, trade, regulation

\begin{abstract}
Abstrak
Terdapat kerancuan manakala mencoba menarik perbedaan yang tegas antara e-commerce dengan e-business. Untuk mensinergikan antara keberlakuan UUITE dengan UU Perdagangan, maka tampaknya diperlukan suatu definisi perantara yang diharapkan dapat membuat titik taut dengan memberikan pengertian tentang Kegiatan Usaha Perdagangan Secara Elektronik yang akan mencakup keseluruhan jenis dan bentuk usaha Perdagangan yang dapat dilakukan dengan Komunikasi Elektronik, sehingga dapat ditarik benang merah bahwa perdagangan secara elektronik mampu merberikan perlindangan hukum kepada penggunan atau konsumen. Berdasarkan pemikiran tersebut di atas, maka perlu ada koordinasi kewenangan antara instansi pembina dan pengawas dari jaringan yakni Kominfo dengan instansi pembina dan pengawas dari tata niaga perdagangan, yakni Kementrian Perdagangan.
\end{abstract}

Kata kunci: e-commerce, perdagangan, peraturan

\footnotetext{
${ }^{1}$ Penulis adalah Dosen Inti Penelitian Bidang Hukum Telematika, dan Ketua Lembaga Kajian Hukum Teknologi, Fakultas Hukum Universitas Indonesia. Alamat kontak: edmon_makarim@yahoo.com.
} 


\section{Latar Belakang}

Dalam perkembangan terakhir pada tahun 2014 ini, Indonesia baru saja mengundangkan UU No. 3 Tahun 2014 tentang Perindustrian ${ }^{2}$ dan UU No.7 Tahun 2014 tentang Perdagangan ${ }^{3}$ yang diharapkan setidaknya akan dapat mendorong industri dan perdagangan sehingga memajukan perekonomian nasional. Selain PP 82/2012 yang merupakan implementasi dari UU ITE, maka UU Perdagangan juga mengamanatkan adanya pembentukan PP untuk pelaksanaan $e$-commerce.

Terkait dengan hal itu, terdapat interseksi antara UU ITE dengan UU Perdagangan serta kewenangan instansi pelaksananya, dimana Kominfo lebih mengemukan istilah e-business sementara Kementrian Perdagangan mengemukakan istilah e-commerce.

Seiring dengan hasil studi United Nations Conference on Trade and Development ("UNCTAD") telah mencermati dinamika e-Commerce di ASEAN yang berkembang demikian pesat, dimana dinyatakan bahwa Indonesia sebagai negara yang cukup tertinggi transaksinya. Sayangnya meskipun Indonesia dikatakan sudah memiliki beberapa ketentuan hukum yang diperlukan untuk e-commerce, namun ternyata masih dikatakan bersifat parsial atau belum sepenuhnya, khususnya dalam hal perlindungan Privacy dan Perlindungan Konsumennya.

2 Pasal 1 ayat (1): Perindustrian adalah tatanan dan segala kegiatan yang bertalian dengan kegiatan industri; ayat (2) Industri adalah seluruh bentuk kegiatan ekonomi yang mengolah bahan baku dan/atau memanfaatkan sumber daya industri sehingga menghasilkan barang yang mempunyai nilai tambah atau manfaat lebih tinggi, termasuk jasa industri; ayat (4). Industri Strategis adalah Industri yang penting bagi negara dan yang menguasai hajat hidup orang banyak, meningkatkan atau menghasilkan nilai tambah sumber daya alam strategis, atau mempunyai kaitan dengan kepentingan pertahanan serta keamanan negara dalam rangka pemenuhan tugas pemerintah negara; ayat (15): Informasi Industri adalah hasil pengolahan Data Industri dan Data Kawasan Industri ke dalam bentuk tabel, grafik, kesimpulan, atau narasi analisis yang memiliki arti atau makna tertentu yang bermanfaat bagi penggunanya; Ayat (16). Sistem Informasi Industri Nasional adalah tatanan prosedur dan mekanisme kerja yang terintegrasi meliputi unsur institusi, sumber daya manusia, basis data, perangkat keras dan lunak, serta jaringan komunikasi data yang terkait satu sama lain dengan tujuan untuk penyampaian, pengelolaan, penyajian, pelayanan serta penyebarluasan data dan/atau Informasi Industri.

${ }^{3}$ Pasal 1 ayat (1): Perdagangan adalah tatanan kegiatan yang terkait dengan transaksi Barang dan/atau Jasa di dalam negeri dan melampaui batas wilayah negara dengan tujuan pengalihan hak atas Barang dan/atau Jasa untuk memperoleh imbalan atau kompensasi; ayat (23): Sistem Informasi Perdagangan adalah tatanan, prosedur, dan mekanisme untuk pengumpulan, pengolahan, penyampaian, pengelolaan, dan penyebarluasan data dan/atau informasi Perdagangan yang terintegrasi dalam mendukung kebijakan dan pengendalian Perdagangan; ayat (24): Perdagangan melalui Sistem Elektronik adalah Perdagangan yang transaksinya dilakukan melalui serangkaian perangkat dan prosedur elektronik. 


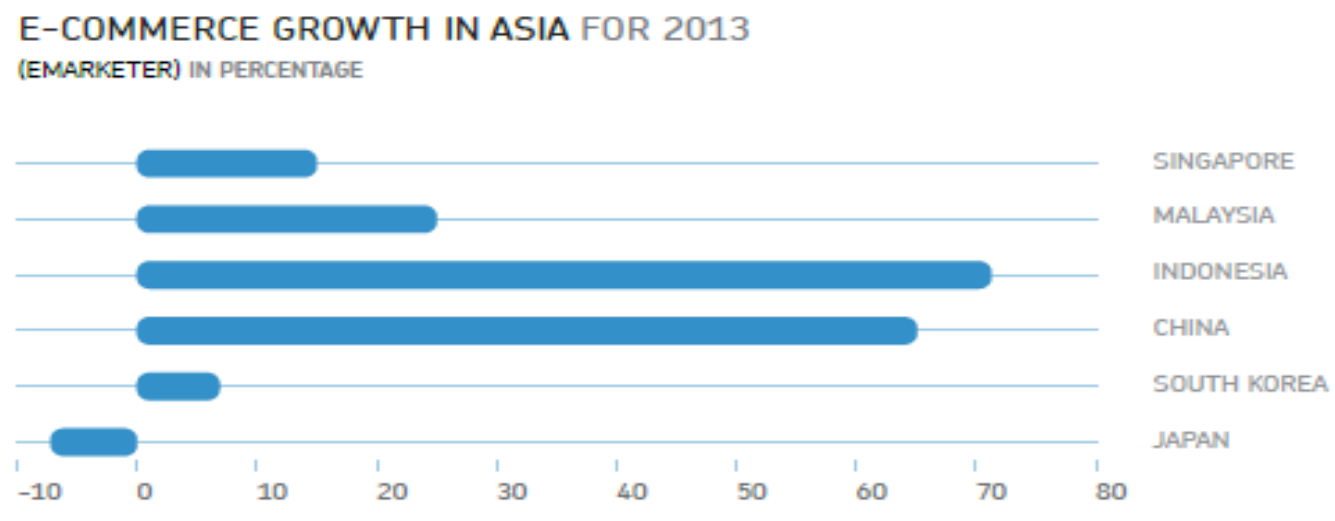

Tabla 1. Status of e-commerce law harmonization in ASEM as of March 2013

\begin{tabular}{|c|c|c|c|c|c|c|}
\hline $\begin{array}{l}\text { Member } \\
\text { Country }\end{array}$ & $\begin{array}{l}\text { Electronic } \\
\text { Transactions }\end{array}$ & Prwacy & Cybererime & $\begin{array}{l}\text { Consumer } \\
\text { Protection }\end{array}$ & $\begin{array}{c}\text { Contant } \\
\text { Regulation }\end{array}$ & Domah Kames \\
\hline $\begin{array}{l}\text { Brunei } \\
\text { Darussalam }\end{array}$ & Enacted & None & Enacted & Partial & Enacted & Enacted \\
\hline Cambodia & Draft & None & Draft & None & Draft & Enacted \\
\hline Indonesia & Enacted & Partial & Enacted & Partial & Enacted & Enacted \\
\hline $\begin{array}{l}\text { Lao People's } \\
\text { Democratic } \\
\text { Republic }\end{array}$ & Enacted & None & None & Draft & Enacted & Partial \\
\hline Malaysia & Enacted & Enacted & Enacted & Enacted & Enacted & Enacted \\
\hline Myanmar & Enacted & None & Enacted & Enacted & Enacted & Enacted \\
\hline Philippines & Enacted & Enacted & Enacted & Enacted & None & Enacted \\
\hline Singapore & Enacted & Enacted & Enacted & Enacted & Enacted & Enacted \\
\hline Thailand & Enacted & Partial & Enacted & Enacted & Partial & Partial \\
\hline Viet Nam & Enacted & Partial & Enacted & Enacted & Enacted & Enacted \\
\hline
\end{tabular}

Source: UNCTAD

Sementara itu, dalam pembahasan isu global e-commerce terakhir yang tengah dibahas di United Nation Commission on International Trade Law ("UNCITRAL"), tengah dibahas tentang penyelesaian sengketa secara elektronik atau Online Dispute Resolution ("ODR"). Sementara seiring dengan itu, di Eropa juga tengah dilakukan revisi hukum terhadap aturan/regulasi perlindungan data pribadi dan juga tanda tangan elektronik serta sertifikasi elektroniknya.

Menjelang ASEAN Community 2015, Indonesia diharapkan harus mampu mempersiapkan segala sesuatunya untuk menghadapi hal tersebut. Oleh karena itu, sangat diperlukan kajian hukum tentang kerangka hukum untuk reformasi kebijakan e-commerce di Indonesia. Penulisan ini akan mengkaji bagaimanakah evolusi kebijakan regional e-commerce (EU vs ASEAN) dan bagaimanakah seharusnya Indonesia membangun kebijakan dan regulasi e-commerce yang mengamankan kepentingan nasional di kawasan ASEAN? 


\section{Pengertian Umum tentang E-Commerce, E-Business dan Komunikasi Elektronik untuk Transaksi Perdagangan}

Seringkali terjadi kerancuan manakala mencoba menarik perbedaan yang tegas antara $e$-commerce dengan $e$-business, karena memang agak sulit ditarik perbedaannya. Secara umum sering dipersepsikan secara limitatif bahwa $e$ commerce lebih dialamatkan kepada sistem perdagangan yang dilakukan secara elektronik melalui Internet (web-commerce/internet-commerce), sehingga sekiranya dilakukan melalui operator telekomunikasi sering disebutkan sebagai mobile-commerce (m-commerce). Sementara e-business lebih dialamatkan kepada sistem perusahaan secara elektronik dalam menjalankan bisnisnya. Dalam penelitian ini, kata kunci yang menjadi pembeda dari e-business dengan e-commerce adalah terletak pada pola hubungan hukum antara para pihaknya. Jika hubungan yang terjadi adalah dalam lingkup internal konteks penyelenggaaan bisnis maka istilah yang tepat adalah e-business, sedangkan jika yang terjadi adalah dalam konteks hubungan eksternal perdagangan dengan konsumen, maka istilah yang lebih tepat adalah e-commerce.

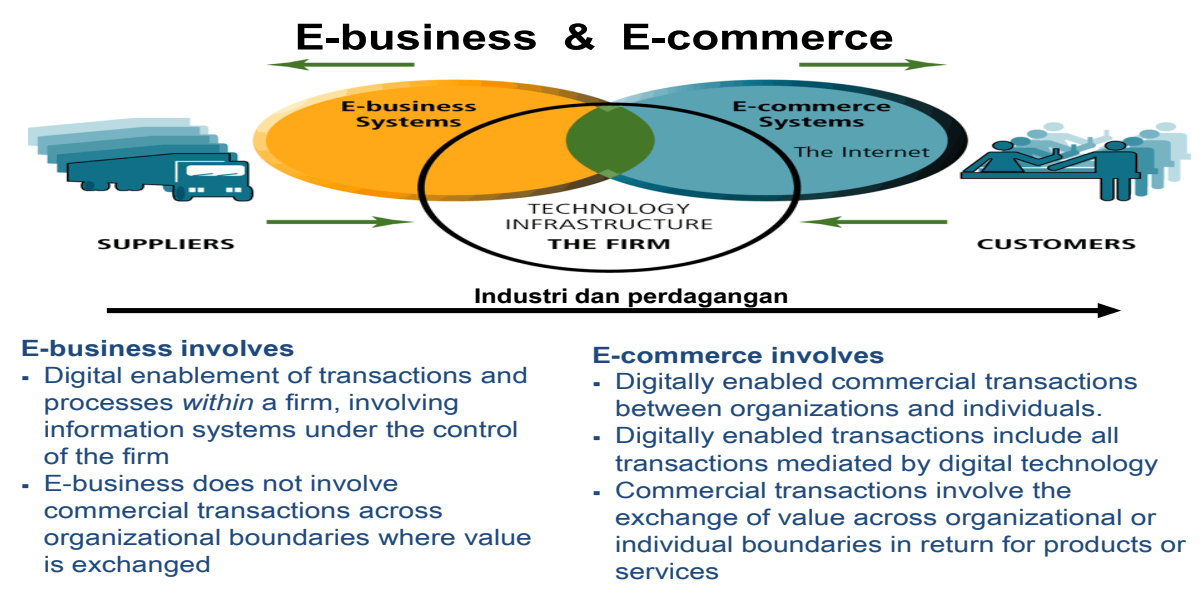

sumber: Kenneth C. Laudon dan Jane C. Laudon

Lebih jauh dari itu, mengingat istilah yang digunakan dalam UU Perdagangan menyatakan bahwa Perdagangan Melalui Sistem Elektronik adalah Perdagangan yang transaksinya dilakukan melalui serangkaian perangkat dan prosedur elektronik, maka dengan mengembalikan kepada lingkup definisi Sistem Elektronik pada UU-ITE, maka penulis melihat kemungkinan penerapannya pada medium yang tidak hanya Internet saja. Dengan kata lain, maka sistem elektronik yang dimaksud dapat mencakup kepada istilah m-commerce. Sesuai dengan UNCITRAL Model Law of ECommerce dan UN-ECC tahun 2005, maka kebijakan dalam RPP Perdagangan Secara Elektronik, sebaiknya juga mengacu kepada pengertian tentang Commercial pada UNCITRAL e-commerce dan definis Komunikasi Elektronik pada article 4 pada UN-ECC, yakni: 
(a) "Communication" means any statement, declaration, demand, notice or request, including an offer and the acceptance of an offer, that the parties are required to make or choose to make in connection with the formation or performance of a contract;

(b) "Electronic communication" means any communication that the parties make by means of data messages;

Dengan demikian, untuk mensinergikan antara keberlakuan UU-ITE dengan UU Perdagangan, maka tampaknya diperlukan suatu definisi perantara yang diharapkan dapat membuat titik taut dengan memberikan pengertian tentang Kegiatan Usaha Perdagangan Secara Elektronik yang akan mencakup keseluruhan jenis dan bentuk usaha Perdagangan yang dapat dilakukan dengan Komunikasi Elektronik, meliputi namun tidak terbatas pada perjanjian jual beli, lisensi, distribusi, keagenan, anjak piutang, konstruksi, konsultasi, investasi, pembiayaan, perekayasaan, asuransi, dan perjanjian komersial lainnya. Penting dipahami bahwa pengertian komunikasi elektronik akan mencakup kepada semua jenis saluran komunikasi secara elektronik, yakni tidak hanya sistem dan jaringan komputer (baik EDI maupun Internet Protocol) melainkan juga sistem tekomunikasi elektronik lainnya (telekomunikasi dan penyiaran).

\section{Evolusi Kebijakan tentang e-Commerce}

Seiring dengan dinamika Internet yang kini lebih mudah diakses secara mobile, telah terjadi evolusi perilaku komunikasi dalam perdagangan dari yang semula berdasarkan media kertas menjadi media elektronik. Internet yang semula hanya untuk mempublikasikan informasi (satu arah) kemudian berubah menjadi pola yang lebih interaktif dan selanjutnya menjadi sarana untuk bertransaksi. Demikian pula dengan mekanisme transaksi dan pembayarannya serta pengirimannya, yang semula penyelesaian transaksi dilakukan secara offline kemudian telah menjadi on-line. Berikutnya dari yang semula dilakukan dengan pembayaran secara tidak langsung dengan penggunaan jasa pihak ketiga kemudian mengarah kepada pembayaran secara langsung antara para pihak dengan penggunaan uang elektronik (digital-cash/e-money). Ringkasnya, pola transaksi perdagangannya kini telah mengarah menjadi one-stop shopping, dimana kesepakatan transaksi adalah mencakup kesepatana atas barang/jasa berikut pembayaran dan pengirimannya, sehingga sekarang akan mencakup (i) arus informasi, (ii) arus uang dan (iii) arus barang. Hal yang menarik untuk dicatat bahwa hal tersebut akan merepresentasikan semua varian yang terjadi pada supply-chain-management dan juga saluran distribusi dari barang/jasa kepada konsumennya.

Selaras dengan itu, dinamika kebijakan tentang e-commerce secara global juga tampak berubah, dari forum yang tidak teregulasi sama sekali kemudian menjadi teregulasi, setidak-tidaknya demi kepastian hukum terhadap adanya penyelenggara transaksi perdagangan yang fair dan juga kepastian 
perlindungan hak konsumen. Secara umum, fenomena Global Framework for e-commerce yang pada intinya melimitasi turut campurnya pemerintah dalam memberikan pengaturan, seakan telah berubah menjadi pengharapan adanya peranan pemerintah untuk tidak lepas tangan atau abai dalam memberikan pengaturan demi perlindungan kepentingan bangsa dan nasionalnya. Kebijakan global yang semula seakan lebih menitikberatkan pada ruang dan kesempatan yang lebih besar kepada sektor swasta/pelaku usaha untuk tumbuh dan berkembang menggerakkan ekonomi digital kini dibarengi dengan amanat untuk lebih memperhatikan terbentuknya trus" dalam e-commerce demi menghargai consumer confidence dalam transaksi yang dilakukannya.

Dilihat dalam perspektif pengguna, maka teknologi akan selalu berkembang dengan arahan untuk selalu memberikan easy to use dan low-cost kepada konsumen. Hal tersebut didukung dengan adanya suatu mekanisme akuntabilitas yang difasilitasi dengan keberadaan suatu tanda yang mencerminkan sertifikasi keandalan (trustmark).

Mike Roberts, Executive Director of eCommerce, Ogilvy \& Mather, talks about how commerce has grown with the intersection of the consumer world and the B2B world. He believes that we're selling in an age where customer experience is largely enabled and it is imperative to have a seamless way of delivery at any touchpoint the customer wants to engage with the brand. The major change is a technology driven focus with mobile, social and data surge and it is the very cornerstone of Continuous Commerce.

\section{Table II}

Factors versus stages in the evolution of e-commerce

\begin{tabular}{|c|c|c|c|}
\hline Factors & $\begin{array}{l}\text { E-commerce } \\
\text { incipiency or informational }\end{array}$ & \begin{tabular}{l}
\multicolumn{1}{c}{ Stages } \\
E-commerce \\
dissemination or B2C
\end{tabular} & $\begin{array}{l}\text { E-commerce } \\
\text { profitability or B2B }\end{array}$ \\
\hline E-network infrastructure & Limited & Extensive & Extensive \\
\hline $\begin{array}{l}\text { Transportation infrastructure } \\
\text { Commercial, banking, }\end{array}$ & Limited & Extensive & Extensive \\
\hline accounting infrastructure & Limited & Adequate & Extensive \\
\hline $\begin{array}{l}\text { Institutional infrastructure } \\
\text { Cultural, demographic. }\end{array}$ & Not important & Important & Very important \\
\hline $\begin{array}{l}\text { educational factors } \\
\text { Costs and minimum disposable }\end{array}$ & Not important & Important & Very important \\
\hline income & Not important & Important & Very important \\
\hline
\end{tabular}

Dalam pembicaraan global, banyak organisasi internasional mengangkat betapa pentingnya perlindungan konsumen terhadap transaksi yang dilakukannya secara online.

OECD Consumers engaging in e-commerce should be afforded transparent and effective consumer protection that is no less than the level of protection afforded in other forms of commerce. 
Consumers should benefit fromFair business advertising and marketing practices; Clear and transparent information disclosures about thek business, product, and transaction (including on a right of withdrawal). Ways to confirm or cancel a transaction before concluding a purchase, Secure and easy-to-use payment mechanisms, Privacy, Education and awareness, Industryself regulation should be encouraged, Member countries should cooperate to combat cross-border fraudulent, misleading and unfair commerce practices

Sehubungan dengan itu, menarik untuk dicermati bagaimana Eropa mengemukan beberapa isu hukum yang harus diselesaikan oleh para negara anggota. Secara umum, kebijakan e-commerce di Eropa akan menyangkut setidaknya beberapa directive, yakni: Dalam perkembangan terakhir, Eropa tengah memperbaiki regulasinya tentang (i) perlindungan data pribadi dan (ii) e-signatures. Dalam konteks privacy, Eropa tengah menerapkan penting right to be forgotten. Sedangkan untuk e-signatures, Eropa menurunkannya menjadi lebih detil dengan istilah e-identification and trust services. Perlu dicatat bahwa demi melindungi kepentingan internal market Eropa, maka kebijakan regional mereka adalah memperlakukan tanda tangan elektronik yang belum terakreditasi di Eropa pada level yang rendah. Dimana pengakuan nilai pembuktiannya belum dianggap setara dengan bukti tertulis di atas kertas. Demi interoperabilitas antara negara eropa, mereka membangun standar penyelenggaraan yang lebih baik.

Secara umum, dari paparan di atas dapat ditarik suatu benang merah untuk kebijakan perdagangan secara elektronik, yakni pada dasarnya perdagangan diarahkan kepada amanat pemberian perlindungan hukum kepada kepentingan pengguna atau konsumen (user's centric). Hal tersebut diturunkan sebagai prinsip-prinsip hukum atau setidak-tidaknya beberapa hal penting yang harus diperhatikan oleh Pelaku Usaha Penyelenggara Perdagangan Secara Elektronik, antara lain:

1. perdagangan harus dibangun atas dasar itikad baik dan menghargai asas keterpercayaan terhadap akuntabilitas sistem elektronik yang baik;

2. perdagangan secara elektronik harus efisien dan efektif sehingga kendala biaya ekonomi tinggi harus ditiadakan;

3. perdagangan diharapkan dapat menumbuhkan iklim persaingan usaha yang sehat; dan

4. perdagangan diharapkan dapat memberikan kemudahan dan melindungi kepentingan konsumen serta mencegah setiap upaya untuk eksploitasi hak-hak konsumen

Dari kerangka kebijakan umum tersebut, maka diperlukan upaya melakukan perbaikan sistem hukum nasional dalam rangka menjalankan kebijakan tersebut 


\section{Kerangka Hukum untuk Reformasi Hukum Nasional}

Dengan memperhatikan dinamika kebijakan dan regulasi sebagaimana telah dipaparkan di atas, maka setidaknya Indonesia perlu mengembangkan pembenahan sebagai berikut:

1. memperjelas kedudukan sektor industri dan perdagangan terhadap produk dan jasa sistem aplikasi dan konten;

2. menjaga netralitas jaringan infrastruktur informasi dan komunikasi sebagai akses pasar dan menjaga pemanfaatan lisensi HKI yang tidak menghambat persaingan usaha yang sehat;

3. menerima dan memperhatikan berbagai kontrak elektronik, yang tidak hanya dipersepsikan sebagai jual beli semata melainkan juga berbagai jenis perikatan lainnya (contoh: lisensi yang bersifat tertutup dan privat dan lisensi yang bersifat publik dan terbuka);

4. Dalam upaya mendorong tercipta penyelenggaraan sistem elektronik perdagangan yang akuntable dan/atau layak dipercaya (trustworthiness), pemerintah perlu memberikan peluang untuk fungsi dan peran profesi penunjang yang terkait TIK termasuk lembaga penyelenggara Trustmark;

5. Terkait dengan koneksi komunikasi untuk transaksi yang aman, perlu didorong kesadaran untuk menggunakan sistem pengamanan dengan teknologi tanda tangan elektronik yang sebaiknya didukung oleh sertifikat elektronik yang berinduk kepada Otoritas Sertifikat Elektronik pemerintah atau Otoritas Sertifikasi Non-Pemerintah yang terakreditasi atau tersertifikasi oleh sistem pemerintah.

\section{Konvergensi Telematika dan Kebijakan yang Kondusif Terhadap Tumbuhnya Industri Jasa dan Produk Aplikasi dan Konten untuk Perdagangan}

Sesuai dengan dinamika konvergensi telematika, maka sebenarnya kebijakan e-commerce tidak dapat terlepas dampak kebijakan dan regulasi terhadap sumber daya komunikasi dan infraktruktur jaringan telekomunikasi. Dalam konteks telematika, isu Perdagangan secara elektronik sesungguhnya berada pada lapisan aplikasi dan konten setelah lapisan penyelenggaraan jaringan sebagai infrastruktur/sarana perdaganganya. Terdapat sedikit perbedaan paradigma antara regulasi terhadap jaringan dengan regulasi terhadap aplikasi dan konten.

Mengingat sumber daya yang bersifat terbatas, maka sumber daya komunikasi (contoh; spektrum frekuensi) dilakukan pengaturan yang ketat dengan rezim perizinan. Hal ini ditujukan dalam rangka menjamin adanya kewajiban konstitusional, yakni demi pemanfaatan untuk sebesarbesarnya kemakmuran rakyat. Dalam konteks infrastruktur, fokusnya adalah untuk dapat menciptakan koneksi, dimana paradigma pembangunannya adalah sebagaimana layaknya pembangunan fisik meskipun dalam pengoperasiannya menggunakan gelombang 
elektromagnetik, sehingga keberadaannya masih terbatas pada lingkup teritorial. Sementara terhadap aplikasi dan konten dapat dikatakan sebaliknya, karena keberadaan aplikasi dan konten dapat bersifat dinamis atau dapat diresepsi secara ubiquotus terlepas dari paradigma batas fisik teritorial. Oleh karena itu dalam penyelenggaraan aplikasi dan konten diatas jaringan yang telah terkoneksi secara global, tidak menganut rezim perizinan, yang sangat logis dapat dilakukan adalah voluntary accreditation terhadap setiap penyelenggaraan untuk kepentingan transaksi perdagangan atau komersial, kecuali jika penyelenggaraan sistem tersebut termasuk dalam lingkup pelayanan publik.

Berdasarkan pemikiran tersebut di atas, maka perlu ada koordinasi kewenangan antara instansi pembina dan pengawas dari jaringan yakni Kominfo dengan instansi pembina dan pengawas dari tata niaga perdagangan, yakni Kementrian Perdagangan. Dengan kata lain, Kementrian Kominfo bertanggung jawab terhadap setiap aspek engineering process, sementara Kementrian Perdagangan bertanggung jawab terhadap setiap aspek business process. Pada sisi teknis, setiap penyelenggaraan sistem elektronik harus memenuhi kelaikan atau akuntabilitas sistem elektronik sesuai standar teknis, sementara pada sisi bisnis setiap penyelenggaraan sistem perdagangan harus memenuhi standar perdagangan (merchantibility). Lebih lanjut, kebijakan terhadap Perdagangan Secara Elektronik dapat diturunkan dalam bentuk koordinasi hubungan kerja, dimana sebelum diberikannya izin penyelenggaraan perdagangan secara elektronik, maka setiap Penyedia Sarana seharusnya melakukan pendaftaran terhadap sistem elektroniknya kepada Kominfo.untuk transaksi elektronik. Dengan demikian, demi melindungi kepentingan publik, pemerintah dapat menyatakan bahwa setiap penyelenggaraan perdagangan secara elektronik berjalan diatas penyelenggaraan sistem elektronik yang akuntabel.

\section{Netralitas Jaringan dan Pemanfaatan HKI yang Tidak Menghambat Iklim Persaingan Usaha yang Sehat}

Mencermati korelasi antara telekomunikasi, perindustrian dan perdagangan, maka akan tampak korelasi bahwa keberadaan bisnis jaringan sesungguhnya adalah sarana yang esensial (essential facilities doctrine) bagi tumbuhnya pasar terhadap penyelenggara jasa dan sarana perdagangan secara elektronik. Demi tumbuhnya industri aplikasi dan konten, maka penyelenggaraan jasa dan jaringan komunikasi harus dapat dipastikan menjalankan prinsip network neutrality dengan baik. Hal ini menjadi isu penting yang telah dibahas dalam Internet Governance Forum.

Selain netralitas jaringan, hal yang mengancam sehatnya pasar industri konten adalah kemungkinan penyalahgunaan Hak Kekayaan Intelektual terhadap aplikasi dan konten itu sendiri. Pada satu sisi Hak Kekayaan Intelektual dibutuhkan untuk perlindungan kepemilikan dan 
nilai ekonomis dari si Intelektual dan Pemegang Hak, namun keberadaan hak esklusif yang diberikan oleh hukum tidak berarti dengan serta merta lahirnya hak monopoli di pasar. Kedua hal itu berbeda fokusnya, oleh karena itu diperlukan kepastian bahwa Hak Kekayaan Intelektual tidak dapat disalahgunakan sehingga dapat mematikan iklim persaingan. Konglomerasi media dan operator jaringan yang mempunyai hubungan terafiliasi malahan akan dapat mengakibatkan adanya penguasaan dari hulu sampai dengan hilir, karena produksi konten berikut saluran distribusi atau penyebarannya berada dalam kondisi rentan akan monopoli ataupun oligopoli.

Dengan demikian, bisnis penyelenggara jaringan dan media serta bisnis industri konten, idealnya tidak memiliki hubungan terafiliasi yang cenderung akan mengakibatkan timbulnya preferensi tertentu dan akan melahirkan kecenderungan penyalahgunaan posisi dominan serta mendorong tindakan diskriminasi terhadap aplikasi dan konten tertentu. Dengan kata lain, terhadap keberadaan aplikasi dan konten yang tidak memiliki alternatif di pasaran, maka keberadaan pelaku usaha penyedia jasa dan jaringan komunikasi dengan penyelenggara perdagangan secara elektronik sebaiknya perlu dipisahkan. Hal tersebut akan membuat terbukanya peluang usaha yang baru bagi pemain yang baru, sehingga potensi nilai ekonomis tidak hanya dinikmati oleh segelintir pihak saja.

\section{Keabsahan Kontrak Elektronik dan Berbagai Jenis Perikatan yang Mendasarinya}

Dalam kegiatan transaksi perdagangan maka hubungan hukum perikatan/kontraktual adalah menjadi penentu sejauh mana tanggung jawab hukum para pihak. Pada prinsipnya, hubungan kontraktual tersebut tetap mengikut syarat sahnya perjanjian. Dalam praktek perdagangan, hukum kontrak dapat mengacu kepada pola yang bersifat formil maupun materil. Dalam perspektif informasi dan komunikasi, maka selain syarat materil (Pasal 1320 KUHPerdata), secara formil kesepakatan sesungguhnya terjadi karena adanya kejelasan informasi yang disampaikan oleh para pihak sebelum berkontrak, baik terhadap identitas dirinya maupun obyek barang/jasa yang diperdagangkannya (precontractual). Dengan informasi tersebut, para pihak mencapai kesepakatan untuk membuat perjanjian (making a contract) guna selanjutnya melakukan hal-hal sebagaimana yang diperjanjikan (performing)

Secara elektronik, hubungan kontraktual sesungguhnya dilakukan secara formil melalui Komunikasi Elektronik dengan tetap mengikuti kaedah persyaratan materil untuk tidak memuat klausul yang tidak fair (unfair contract terms). Secara teknis, transaksi dilakukan secara jarak jauh melalui sarana komunikasi elektronik, dimana kontrak terjadi akibat bertemunya syarat dan kondisi dalam suatu penawaran secara elektronik (Offer) dengan kondisi penerimaan/persetujuan secara elektronik 
(Acceptance). Namun mengingat obyek tidak mungkin dapat diresepsi secara sempurna secara elektronik, maka logisnya harus diberikan kesempatan kepada konsumen untuk dapat membatalkan perjanjian jika ternyata keberadaan obyek tidak sebagaimana yang diharapkan dan/atau diperjanjikan. Calon pembeli/pengguna harus diberikan kesempatan untuk waktu tertentu melakukan pembatalan tersebut dengan konsekwensi pengembalian biaya administratif. Dalam pembuatan RPP semua kondisi tersebut perlu diatur agar tercipta praktek perdagangan yang adil (fair trade practices).

Penting juga untuk dicermati bahwa kontrak elektronik dapat mencakup beberapa jenis perikatan, baik jual beli (pengalihan atau pemindahan hak kepemilikan) maupun lisensi (pemberian hak tertentu). Keberadaan lisensi dalam perundang-undangan yang mengatur hak kekayaan intelektual baru sebatas pemahaman tentang perlindungannya sebagai hak kebendaan, namun belum menyentuh kepada perspektif tata niaga perdagangan. Dalam perspektif perdagangan, keberadaan lisensi adalah cerminan dari keberadaan business model sehingga tidak boleh hanya dipersepsikan dalam bentuk yang proprietary saja melainkan harus juga mengakomodir keberadaan perkembangan lisensi yang terus berkembang seperti lisensi publik maupun lisensi creative commons. Lisensi proprietary lazim digunakan dalam konteks komersialisasi suatu konten yang dianggap sebagaimana layaknya produk barang, sementara model lisensi yang lain lebih memposisikannya sebagai bentuk komersialisasi dalam bentuk jasa.

Dalam konteks lingkup perdagangan hubungan kontraktual lazimnya akan mencakup (i) hubungan antara pelaku usaha (B2B), (ii) hubungan antara pelaku usaha dengan konsumen (B2C), atau (iii) hubungan dagang antara individu konsumen (C2C). Sementara untuk hubungan antara Pemerintah dengan Pelaku Usaha (G2B) telah diatur dalam peraturan tentang pengadaan barang dan jasa (procurement), sedangkan hubungan transaksional antara pemerintah dengan penduduk (G2C) juga telah diatur dalam hubungan pelayanan publik. Setiap hubungan hukum tersebut tentunya akan mempunyai pengaturan dan standar penyelenggaraan yang berbeda sesuai karakteristik posisi tawar (bargaining position) dan kesetimbangan kepentingan hukum yang sah antara keduanya.

\begin{tabular}{|l|l|l|}
\hline B2B & B2C & C2C \\
\hline Posisi tawar menawar & Posisi tawar menawar & Posisi tawar menawar \\
dianggap seimbang & dianggap tidak seimbang, & dianggap seimbang \\
sehingga dikembalikan & dimana konsumen rentan & sehingga dikembalikan \\
kepada kesepakatakan & akan eskpolitasi dari & kepada kesepakan para \\
para pihak dalam & pelaku usaha, sehingga & pihak, namun setiap pihak \\
menentukan pilihan & kesepakatan harus & harus memenuhi iktikad \\
hukum dan pilihan forum & mengacu kepada prinsip2 & baik dan kepercayaan \\
penyelesaian sengketa & perlindungan konsumen, & serta kejujuran dalam \\
\hline
\end{tabular}




\begin{tabular}{|l|l|l|}
\hline & $\begin{array}{l}\text { dan pilihan hukum serta } \\
\text { forum harus yang } \\
\text { memudahkan } \\
\text { konsumen }\end{array}$ bagi & $\begin{array}{l}\text { menyampaikan informasi } \\
\text { obyek barang/jasa yang } \\
\text { ditawarkan. }\end{array}$ \\
\hline
\end{tabular}

\section{Jaminan Akuntabilitas dan Interoperabilitas Sistem Elektronik untuk Perdagangan}

Terkait dengan syarat sahnya perjanjian, perlu dicermati bahwa secara teknis bahwa kejelasan tentang hal tertentu tidak hanya terhadap obyek yang diperdagangkan melainkan juga kejelasan terhadap akuntabilitas sistem elektronik yang diselenggarakan itu sendiri. logika teknis dan hukumnya adalah jika sistem tidak berjalan sebagaimana mestinya maka hubungan komunikasi antara para pihak tidak pernah terjadi dan konsekuensinya perikatan pun dianggap tidak pernah terjadi. Berdasarkan pasal 15 UU ITE, Setiap penyelenggara diasumsikan secara hukum untuk selalu bertanggung jawab (presumed liability) bahwa sistem elektronik diselenggarakannya handal, aman dan berkerja sebagaimana mestinya. terhadap setiap penyalahgunaan sistem maka penyelenggara harus bertanggung jawab penuh terhadap setiap kerugian yang terjadi. Dalam penyelenggaraan tersebut, tanggung jawab akan melekat kepada setiap pihak yang mempunyai kontribusi penyelenggaraan sistem tersebut kepada publik, hal tersebut tidak hanya menyangkut Operator semata melainkan juga mencakup setiap pihak yang berkontribusi dalam penyelenggaraan sitem elektronik itu.

Dalam konteks perdagangan keterhubungan antara sistem elektronik adalah menjadi suatu keniscayaan, hal tersebut terwujud dalam penyelenggaraan yang terhubung pada satu aturan/protokol komunikasi yang digunakan. Jika aturan protokol komunikasi itu adalah sarana komunikasi umum, maka dengan sendirinya setiap pihak yang menghubungkan diri pada protokol tersebut harus mengetahui karakteristik protokol komunikasi itu sendiri. Dalam hal ini, Internet protokol adalah komunikasi terbuka yang menjanjikan kecepatan namun rentan akan keamanan (distributed networks) karena pada dasarnya ia adalah seperti penyampaian informasi yang berantai. Setiap pihak yang meneruskannya punya potensi untuk mengetahui dan mengubah informasi tersebut. Hal tersebut berbeda halnya dengan protokol komunikasi EDI dan protokol telekomunikasi konvensional, yang menekankan pada komunikasi yang cenderung sentralistis pada sisi penyelenggaranya. Dengan sendirinya, maka komunikasi perdagangan melalui Internet selayaknya adalah tidak laik dipercaya kecuali jika dalam pemanfaatannya memenuhi kaedah-kaedah dalam keamanan informasi dan/atau komunikasi (secured communication), yakni; kerahasiaan, keutuhan, ketersediaan, otorisasi/keautentikan, dan nirsangkal/tak dapat ditampik. 
Secara tidak langsung maka terhadap semua informasi elektronik yang menjadi dasar berkontrak harus terjamin keautentikan atau reliabilitasnya demi kekuatan pembuktian di belakang hari. Dengan sendirinya, jika tidak ada keamanan berarti akan berkonsekwensi lemahnya pembuktian, dan sebaiknya terhadap sistem yang seperti itu jangan dijadikan sebagai sarana untuk melakukan hubungan kontraktual ( no security $=$ no evidence $=$ no deal $)$.

\section{Penerimaan Bukti Elektronik, Tanda Tangan Elektronik dan Otoritas Sertifikat Elektronik sebagai Alat Bukti yang Sah untuk Perdagangan}

Terkait dengan akuntabilitas dan keterpercayaan terhadap sistem elektronik, dalam menentukan bobot pembuktian suatu informasi elektronik atau kontrak elektronik, diperlukan perhatian terhadap reliabilitas keamanan sistem elektronik itu sendiri, baik dalam konteks sistem informasi maupun sistem komunikasi yang digunakan. Pasal 5 UU ITE telah menyatakan bahwa Informasi Elektronik dapat menjadi suatu alat bukti yang sah, namun sejauh mana ia dapat memiliki sifat kekuatan yang mengikat dalam pembuktian ditentukan oleh aspek reliabilitasnya. Konsekuensi pasal 5 UU ITE adalah kehadiran suatu informasi elektronik sebagai alat bukti selayaknya tidak dapat ditampik hanya karena atas dasar bentuknya yang elektronik, namun hal tersebut harus dilihat bagaimana kesetaraan fungsionalnya (functional equivalent approach) seperti layaknya bukti tulisan di atas kertas. Hal itu dapat melihat kepada sistem keamanan atau keautentikannya (e-authentication) yang salah satunya adalah penggunaan teknologi Tanda Tangan Elektronik. Dengan kata lain, sistem keautentikan secara elektronik adalah ekuivalen dengan penggunaan tanda tangan elektronik.

Dalam penyelenggaraan tanda tangan elektronik, sesungguhnya yang terjadi adalah adanya suatu proses pengidentifikasian terhadap identitas subyek hukum yang bertanggung jawab, mencakup validitas identitas data pribadi dan juga keutuhan informasi serta keamanan media penyimpan atau media komunikasinya. Level kekuatan pembuktian yang tertinggi adalah apabila TTE didukung oleh suatu Sertifikat Elektronik yang diterbitkan oleh Otoritas Sertifikat Elektronik yang terakreditasi atau tersertifikasi secara nasional dimana ia berinduk kepada Penyelenggaraan Sertifikat Elektronik Pemerintah.

Perlu dicermati bahwa ketentuan dalam UU ITE dan PP-PSTE sesungguhnya baru mengatur dalam konteks keautentikan informasi namun belum kepada fungsi approval untuk menjelaskan adanya suatu niatan untuk melakukan transaksi perdagangan. Oleh karena itu dalam RPP e-commerce sebaiknya mengatur lebih lanjut tentang pemanfatan TTD dalam konteks transaksi perdagangan. Ketentuan harus dapat menerima dari nilai pembuktian yang paling lemah sampai dengan yang 
paling kuat dengan dasar kriteria adanya akreditasi terhadap sistem elektronik.

\section{Sistem Pembayaran dan Sistem Pengiriman Secara Elektronik}

Terkait dengan mekanisme transaksi, umumnya dapat diperjanjikan dalam satu paket penyelenggaraan yang dapat saja mencakup keberadaan sistem pembayaran dan juga sistem pengiriman barang/jasa yang dapat dipilih oleh penggunanya. Jika hal tersebut diatur dalam fitur kondisi penawaran, maka seharusnya hubungan kontraktual antara pelaku usaha tersebut harus jelas dan merupakan hasil kerjasama bisnis dari para pembisnis tersebut. Tentunya mereka harus mempunyai hubungan yang khusus dan tetap, dan hal tersebut idealnya juga disampaikan kepada konsumen.

Secara umum berlaku kebijakan secure and easy to use payment bagi konsumen. Sehubungan dengan itu, keberadaan sistem pembayaran yang digunakan harus memperhatikan kebijakan suatu negara dalam menjaga stabilitas moneternya dan juga memperhatikan kewenangan instansi terkait yang bertugas menjaga kelancaran sistem pembayaran.

Fenomena terakhir yang menarik untuk dicermati adalah adanya suatu sistem pembayaran secara elektronik yang didasarkan atas penggunaan kriptografi (crypto-currency) yang bersifat peer-to-peer (P2P) dalam komunitas internet, yang meskipun diterima oleh para pihak namun sesungguhnya tidak dapat diyakini akuntabilitas penyelenggaraanya, bahkan dalam prakteknya cenderung digunakan untuk transaksi yang bersifat melawan hukum (contoh; obat bius, pencucian uang, dan sebagainya) karena ditujukan untuk memfasilitasi yang bersifat anonimous.
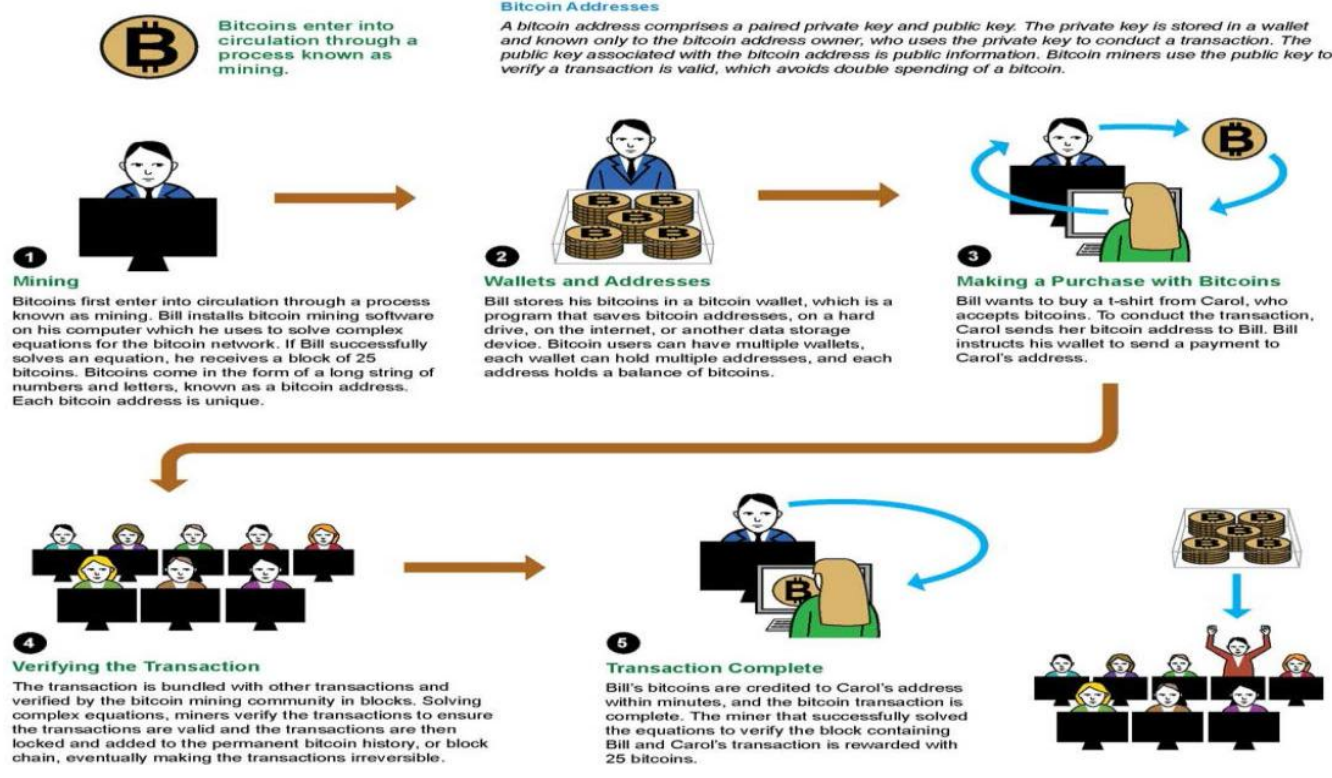

Figure 1 
Berbeda dengan beberapa negara yang jelas menyatakan melarang, Indonesia cq Bank Indonesia tidak menyatakan secara tegas sebagai sistem pembayaran yang terlarang, melainkan lebih menyatakannya sebagai salah satu bentuk investasi yang tidak diatur namun juga tidak dilarang. Konsekuensi atas resiko dikembalikan kepada para pihak. Kebijakan yang seperti itu, dapat dikatakan tidak tepat karena seakan negara lepas tangan untuk melindungi warga negaranya yang karena ketidaktahuannya atau karena kebodohannya sendiri menjadi mangsa orang lain. Padahal secara makro hal tersebut dapat berdampak kepada arus moneter, karena pada faktanya telah terjadi pengkonversian rupiah menjadi mata uang digital yang tidak dikenal siapa penanggung jawabnya.

Demi memastikan perlindungan konsumen dan.arus moneter, sebaiknya pemerintah menyatakan larangan, kecuali bagi yang jelas penyelenggara dan mekanisme perlindungan konsumennya dan/atau tidak merugikan kepentingan ekonomi nasional. Sebagai salah satu contohnya adalah kepastian bagi pemilik bitcoin untuk dapat mencetaknya secara fisik dalam bentuk logam emas, dengan demikian maka asumsi persamaan dengan salah satu bentuk investasi memang terpenuhi.

\section{Pajak dan Bea Materai}

Terkait dengan kebijakan finansial negara, setidaknya terdapat dua hal yang sangat berkaitan dengan tumbuhnya manfaat $e$-commerce bagi bangsa Indonesia, yakni (i) perihal perpajakan ${ }^{4}$ dan (ii) pengenaan bea materai (duty of stamp). Sesuai konstitusi, Pasal 23A menyatakan bahwa Pajak dan pungutan lain yang bersifat memaksa untuk keperluan negara diatur dengan undang-undang. Sayangnya mencermati pasal 1 angka (1) UU No.6 Tahun 1983 yang terakhir diubah dengan 16 Tahun 2009 tentang Ketentuan Umum dan Tata Cara Perpajakan, Pajak adalah kontribusi wajib kepada negara yang terutang oleh orang pribadi atau badan yang bersifat memaksa berdasarkan Undang-Undang, dengan tidak

\footnotetext{
${ }^{4}$ Delapan hukum dasar perpajakan di Indonesia meliputi: (1) Undang-undang Ketentuan Umum dan Tatacara Perpajakan/UUKUTp" Undang-undang No. 6/1983, diganti dengan Undang-undang no.16/2000; (2) "Undang-undang Pajak Penghasilan/UU PPh": Undangundang No.7/1983, diubah dengan Undang-undang No. 17/2000; (3) "Undang-undang Pajak Pertambahan Nilai atas Barang dan Jasa dan Pajak Penjualan atas Barang Mewah"/UU PPN/PPn BM ): Undang-undang No. 8/1983, diubah dengan Undang-undang No. 18/2000; (4) "Undang-undang Pajak Bumi dan Bangunan - UU PBB"): Undang-undang No. 12/1985 diubah dengan Undang-undang No. 12/1994; (5) "Undang-undang Penagihan Pajak dengan Surat Paksa/UU PPSP") Undang-undang No. 19/1997, diubah dengan Undang-undang No. 19/2000; (6) "Undang-undang Bea Perolehan Hak atas Tanah dan Bangunan/UU BPHTB") Undangundang No. 21/1997 diubah dengan Undang-undang No. 20/2000; (7) "Undang-undang Pengadilan Pajak/UU PP": Undang-undang No. 14/2002; (8) "Undang-undang Bea Meterai/UU BM" pendek kata: Undang-undang No. 13 of 1985.
} 
mendapatkan imbalan secara langsung dan digunakan untuk keperluan negara bagi sebesar-besarnya kemakmuran rakyat. Secara filosofis hal tersebut terasa agak kurang sejalan dengan hakekat bahwa negara dibentuk sebagai perwujudan kontrak sosial untuk mensejahterakan bangsanya, karena selayaknya amanat pembukaan UUD alinea ke 4 menugaskan bahwa pemerintah dibentuk untuk melindungi dan mencerdaskan bangsanya serta untuk memajukan kesejahteraan umum. ${ }^{5}$ Sementara jika yang dibicarakan adalah bentuk kontraprestasi oleh negara maka hal tersebut masuk dalam lingkup retribusi daerah berdasarkan UU No.28 Tahun 2009 tentang pajak daerah dan retribusi daerah. $^{6}$

Terkait dengan kontrovesi perpajakan terhadap e-commerce, Ditjen Pajak memandang bahwa e-commerce dikembangkan untuk memfasilitasi penjual dan pembeli untuk berjumpa dalam satu layanan di internet. $^{7}$ Mengikuti perkembangan teknologi yang sekarang sudah semakin pesat, seperti e-commerce, Ditjen Pajak menyikapinya sebagai perubahan moda transaksi jual beli. Perkembangan teknologi disikapi sebagai perubahan proses bisnis namun tidak serta merta merubah proses bisnis perpajakan.

Direktur Transformasi Proses Bisnis, Wahju Karya Tumakaka menjelaskan dengan e-commerce, masyarakat bisa mendapatkan fasilitas market place. Artinya e-commerce yang menyediakan tempat bagi penjual dan pembeli untuk berjumpa dalam satu layanan di internet. Tidak ada yang berubah dari proses bisnis perpajakan untuk e-commerce, di mana perusahaan e-commerce tetap harus mengikuti ketentuan perpajakan yang sama dengan pelaku usaha konvensional. Hal tersebut dipertegas oleh Kasubdit Manajemen Transformasi, Nufransa Wirasakti,

\footnotetext{
${ }^{5}$ Alinea ke-4 Pembukaan UUD Negara RI: "Kemudian dari pada itu untuk membentuk suatu Pemerintah Negara Indonesia yang melindungi segenap bangsa Indonesia dan seluruh tumpah darah Indonesia dan untuk memajukan kesejahteraan umum, mencerdaskan kehidupan bangsa, dan ikut melaksanakan ketertiban dunia yang berdasarkan kemerdekaan, perdamaian abadi dan keadilan sosial, maka disusunlah Kemerdekaan Kebangsaan Indonesia itu dalam suatu UndangUndang Dasar Negara Indonesia, yang terbentuk dalam suatu susunan Negara Republik Indonesia yang berkedaulatan rakyat dengan berdasarkan kepada Ketuhanan Yang Maha Esa, Kemanusiaan Yang Adil dan Beradab, Persatuan Indonesia dan Kerakyatan yang dipimpin oleh hikmat kebijaksanaan dalam Permusyawaratan/Perwakilan, serta dengan mewujudkan suatu Keadilan sosial bagi seluruh rakyat Indonesia."

${ }^{6}$ Pasal 1 angka (10): Pajak Daerah, yang selanjutnya disebut Pajak, adalah kontribusi wajib kepada Daerah yang terutang oleh orang pribadi atau badan yang bersifat memaksa berdasarkan Undang-Undang, dengan tidak mendapatkan imbalan secara langsung dan digunakan untuk keperluan Daerah bagi sebesar-besarnya kemakmuran rakyat; angka (64): Retribusi Daerah, yang selanjutnya disebut Retribusi, adalah pungutan Daerah sebagai pembayaran atas jasa atau pemberian izin tertentu yang khusus disediakan dan/atau diberikan oleh Pemerintah Daerah untuk kepentingan orang pribadi atau Badan.
}

Ditjen Pajak Sikapi Perkembangan E-Commerce Dengan Bijak $<$ http://www.pajak.go.id/content/ditjen-pajak-sikapi-perkembangan-e-commerce-denganbijak> 
yang mengatakan tidak ada jenis pajak yang baru bagi pelaku usaha $e$ commerce, sehingga diperlakukan sama dengan pelaku usaha konvensional. Yang diawasi adalah kepatuhan perpajakannya. "Kami sudah melakukan kajian untuk meningkatkan kepatuhan wajib pajak $e$ commerce." ungkapnya.

Sementara Kasubdit Pengembangan Penegakan Hukum, Yulianingsih menyatakan bahwa Ditjen Pajak mulai mengawasi pelaku usaha e-commerce dengan memanfaatkan kecanggihan teknologi informasi. Dalam hal ini, Ditjen Pajak berharap para pelaku usaha $e$ commerce tidak menyembunyikan omzetnya, sehingga memenuhi kewajiban perpajakannya dengan sebenar-benarnya seperti pelaku usaha konvensional.

Sehubungan dengan itu, Ditjen Pajak telah mengeluarkan SE Nomor SE-62/PJ/2013 entang PenegasanKetentuan Perpajakan Atas Transaksi E-Commerce. Mereka mencermatinya dalam 4 hal, yakni bisnis portal, retail, database dan Penulis mencermati bahwa terhadap hal-hal yang pada dasarnya adalah bisnis yang ada sebelum online kemudian di online kan mungkin hal tersebut dapat dikatakan cukup. Namun untuk modelmodel bisnis yang justru baru terlahir akibat Internet, maka pendekatakan pengenalan bisnis dengan model paradigma transformasi dapat dikatakan tidak sepenuhnya tepat. Hal tersebut selayaknya mempertimbangkan terlebih dahulu bagaimana aktivitas komersial itu dilakukan. Sebagai contohnya adalah bisnis penyelenggaraan trust yang belum tergali dengan baik.

Mencermati semua pernyataan tersebut di atas, tampaknya pengenaan pajak yang konvensional terhadap penghasilan dan pertambahan nilai harus menjadi perhatian penting. Salah satu kendala pengenaan PPH adalah penentuan Bentuk Usaha Tetap untuk dimana dilakukannya transaksi tersebut. Hal tersebut selalu dibenturkan dengan pemahaman yang keliru tentang kemayaan yang seolah-olah hal tersebut tidak dilakukan dalam yurisdiksi hukum Indonesia. Padahal semua yang terjadi di Internet pada dasarnya adalah berada pada kondisi yang ubiquotus, yakni hal tersebut terjadi pada saat yang sama (meskipun catatan waktunya berbeda antara negara) dan pada lokasi yang berbedabeda.

Pada sisi yang lain, juga sangat disadari oleh pelaku usaha yang bersangkutan bahwa go to Internet berarti go global yang artinya mereka sadar melakukan penawaran secara elektronik dengan niatan untuk memasuki wilayah hukum negara konsumen. Patut dicatat bahwa penghasilan yang diperoleh oleh pelaku usaha yang bersangkutan justru terjadi adanya transaksi oleh Konsumen Indonesia. Dengan demikian, patutkah dibiarkan bahwa pajak penghasilan dinikmati oleh negara pelaku usaha yang bersangkutan, sementara Indonesia memajaki PPN si Konsumen.

Hal tersebut semakin ironis manakala hal tersebut dibiarkan terhadap kebendaan yang secara kepemilikan intelektual berada pada bangsa asing 
sementara bangsa Indonesia hanya diberikan lisensi untuk hak menggunakan. Negara justru seakan tidak memungut royalti income yang seharusnya dapat dipungut dan lebih menyukai untuk memungut PPN yang dibebankan kepada konsumen. Padahal dalam pengenaan biaya lisensi terdapat sekian persentasi royalti income dari si pemilik hak cipta yang bersangkutan. Lalu dimana manfaat bagi negara kita terhadap penghargaan hak cipta milik bangsa lain, padahal bangsa kita akan diberikan sanksi jika tidak menghargai hak cipta mereka. Justru lucunya, kita lebih menyukai mempidanakan bangsa sendiri, padahal tanggung jawab atas produk tersebut dan standar laik dagang dapat dikatakan belum jelas melindungi hak konsumen Indonesia.

Dalam konteks e-commerce, sebaiknya perlu dipertimbangkan tentang pembedaan antara Pedagang dengan Penyedia Sarana Perdagangan Secara Elektronik dalam konteks transaksi lintas negara. Kebijakan untuk hanya mengejar kepada PPN, tampaknya justru tidak produktif dan cenderung merendahkan kedudukan bangsa Indonesia sendiri karena seakan melepaskan penghasilan yang diberikan oleh bangsa kita kepada bangsa lain. Hal tersebut akan menjadi benefit mereka untuk berupaya agar tidak dinyatakan sebagai BUT di Indonesia.

Sementara itu, terkait dengan fungsi keautentikan terhadap dokumen elektronik, selama ini iklim perniagaan dibebani oleh praktek yang sesungguhnya tidak sesuai dengan keberlakukan UU No.13 Tahun 1985 tentang Bea Meterai. Dalam prakteknya sekarang ini para penyelenggara sistem elektronik (termasuk bank dan operator telekomunikasi) menerapkan keberlakuan UU Meterai secara sepihak padahal hal tersebut membebani konsumen. Meskipun dokumen penagihan hanya diberikan kepada yang bersangkutan dan dikirimkan secara email, pengenaan bea meterai tetap dinyatakan dan yang harus menanggung adalah konsumen. Dengan sendirinya menjadi suatu pernyataan yang unik, ternyata meskipun sudah disepakati untuk menerima tagihan secara elektronik hal itu ternyata masih membebani konsumen.

Diteliti lebih lanjut maka dalam pasal 1 UU Bea Meterai telah dinyatakan bahwa dengan nama Bea Meterai dikenakan pajak atas dokumen yang disebut dalam Undang-undang ini. Sedangkan dalam ayat (2) dinyatakan bahwa dalam UU Bea Meterai yang dimaksud dengan Dokumen adalah kertas yang berisikan tulisan yang mengandung arti dan maksud tentang perbuatan, keadaan atau kenyataan bagi seseorang dan/atau pihak-pihak yang berkepentingan. Oleh karena itu selayaknya paradigma pemeteraian hanya dapat diterapkan dalam lingkup bukti kertas agar ia sejalan dengan sifat benda meterai itu sendiri dalam ayat (2) butir (b) yang menyatakan bahwa Benda meterai adalah meterai tempel dan kertas meterai yang dikeluarkan oleh Pemerintah Republik Indonesia;

Sekiranya hal ini masih ingin diterapkan maka selayaknya pemeteraian hanya dilakukan dalam konteks dokumen autentik elektronik pejabat, dimana dapat dipastikan bahwa selain fungsi budgetair tercapat, 
fungsi keautentikan pun menjadi dapat dicapai. Pejabat yang bersangkutan dapat menyatakan bahwa meterai nomor tertentu memang melekat pada suatu dokumen publik tertentu, sehingga hal tersebut memang dapat memperkuat nilai pembuktian di belakang hari.

Berdasarkan uraian tersebut di atas, maka dapat dikatakan bahwa selayaknya suatu dokumen yang elektronik tidak diberlakukan UU Bea Meterai. Untuk menjawab penerapan yang tidak sesuai hukum tersebut, maka konsekuensinya RPP e-commerce harus menyatakan bahwa terhadap bukti kontrak elektronik tidak diterapkan UU Bea Meterai. Hal ini akan membuat efisiensi dan menjadi insentif dalam transaksi secara elektronik baik nasional maupun lintas negara. ${ }^{8}$

\section{Perlindungan Konsumen dan Penyelenggaraan Sertifikasi Keandalan}

Pada dasarnya dapat dikatakan bahwa hak konsumen yang relevan dengan e-commerce adalah (i) hak atas keamanan dan kenyamanan Konsumen, khususnya atas Privasi dan data pribadinya, (ii) hak atas kejelasan informasi sebelum melakukan kontrak elektronik, dan (iii) hak mendapatkan sesuatu barang dan/atau jasa yang sesuai dengan ekspektasi dan/atau sepadan dengan biaya yang dikeluarkannya.

Secara umum telah dipahami bahwa hak atas keamanan dan kenyamanan adalah tidak hanya menyangkut kepada penyelenggaraan sistem yang aman baik secara fisik maupun logik dari penyelenggara, melainkan juga mencakup segala sesuatu pada sistem elektronik yang berdampak kepada privasi dan data pribadi konsumen. Hal itu tentunya akan mencakup identitas dan data pribadi konsumen berikut pola perilakunya dalam berbelanja (profiling).

Dalam setiap transaksi yang dilakukannya, umumnya konsumen harus mengisi data pribadi kepada pelaku usaha, namun sayangnya hal tersebut tidak diimbangi dengan adanya kewajiban hukum penyelenggara untuk menjamin bahwa perolehan, penyimpanan dan penggunaannya tidak akan digunakan secara melawan hukum. Pada sisi yang lain, seringkali Pelaku Usaha berpikir bahwa data konsumen adalah rahasia dagang pelaku usaha yang menjadi properti miliknya sehingga ia dapat share dengan pihak lain dan mengambil keuntungan dari padanya. Oleh karena itu, isu spamming di Indonesia dapat dikatakan seakan semakin marak, tidak hanya via Internet melainkan juga via komunikasi seluler. Sementara, aturan yang digagas oleh BRTI cenderung lebih memihak kepentingan penyelenggara telekomunikasi ketimbang pengguna, bahkan mereka lebih condong untuk menerapkan Do-not-Call-Registry yang dibangun atas paradigma Option-Out Policy ketimbang paradigma

\footnotetext{
${ }^{8}$ Pasal 5: Saat terhutang Bea Meterai ditentukan dalam hal: (a). dokumen yang dibuat oleh satu pihak, adalah pada saat dokumen itu diserahkan; (b). dokumen yang dibuat oleh lebih dari satu pihak, adalah pada saat selesainya dokumen itu dibuat; (c). dokumen yang dibuat di luar negeri adalah pada saat digunakan di Indonesia.
} 
Option In Policy, padahal tidak ada satu pun ketentuan dalam UU Perlindungan Konsumen dan UU ITE yang memungkinkan adanya hal tersebut.

Berdasarkan kondisi yang sekarang ini, sebenarnya pasal 22 UU ITE dan pasal 15 PP-PSTE telah memberikan panduan adanya standar penyelenggaraan perlindungan data pribadi konsumen, meskipun belum sempurna. Paralel dengan itu, Kominfo juga tengah mendorong dibuatnya UU Perlindungan Data dan Informasi Pribadi yang akan mengikuti standar perlindungan ala Eropa. Penting untuk dicatat bahwa standar perlindungan privasi antara Eropa dan Amerika Serikat cukup berbeda secara signifikan. Dalam hal ini, dengan mengacu kepada APEC Privacy Framework, maka sebaiknya Indonesia perlu melakukan ketentuan hukum yang bersifat hibrida, sehingga Indonesia dapat dikatakan memenuhi standar perdagangan dunia.

Terkait dengan itu, untuk menjamin adanya consumer confidence terhadap perlindunga privacy, APEC mengamanatkan ruang bagi Accountability Agent untuk memastikan diterapkannya kaedah-kaedah hukum perlindungan data pribadi. Menariknya pasal 15 PP-PSTE dapat dikatakan memiliki ketentuan tersebut khususnya dengan adanya pengaturan terhadap sertifikasi keandalan (trust-mark) yang tidak berbeda dengan pengertian dengan Accountability Agent. Sesungguhnya, sertifikasi keandalan adalah salah satu bentuk pemberdayaan fungsi dan peran pihak ketiga yang profesional untuk menjamin bahwa business practices adalah menghargai hak-hak konsumen. Dengan kata lain, ketentuan tentang trustmark sesungguhnya adalah titik temu atau jembatan perantara antara adanya jaminan pelaku usaha untuk menerapkan fair trade practices dengan perlindungan hak konsumen.

Sehubungan dengan itu, Konsumen Indonesia juga tengah menghadapi adanya penerapan periklanan yang cenderung mengganggu (intrusive). Pemasangan iklan yang dilakukan oleh operator pada pertama kali pengguna untuk memasuki Internet, dapat dikatakan sebagai suatu kegiatan yang jelas mengganggu kenyamanan konsumen dan tidak merupakan core business dari si operator yang bersangkutan. Operator dapat dikatakan mempunyai lini bisnis dalam konteks jaringan dan akses bukan pada sisi konten.

\section{Tanggung Jawab Penyedia Sistem Perantara}

Dalam konteks sistem elektronik, khususnya Internet pihak penyelenggara dapat dibedakan atas (i) penyelenggara infrastruktur komunikasi, (ii) penyelenggara sistem aplikasi dan/atau konten baik yang sebagai market maupun yang sebagai penyedia jasa penyelesaian transaksi. Penyelenggara infrastruktur komunikasi elektronik seringkali dipahami tidak mempunyai motif terhadap tujuan pencarian dan akses suatu informasi di Internet karena menyalurkan setiap orang sesuai apa yang diketikannya pada sistem. 
Sehubungan dengan kemungkinan adanya konten yang melawan hukum yang berada pada ruang si penyelenggara, secara umum telah menjadi best practices adanya notice and take-down policy. Pada intinya, kebijakan ini memberikan ruang bagi setiap pihak yang merasa dirugikan dapat melaporkan atau mengadukan adanya suatu illegal content pada sistem penyelenggara. Namun pada sisi lain, penyelenggara memerlukan adanya suatu kepastian hukum untuk tidak dapat digugat oleh pihak yang menggunggah konten tersebut di Internet, jika mereka menjalankan dan melakukan kebijakan tersebut.

\section{Penyelesaian Sengketa Secara Elektronik}

Meskipun pembicaraan tentang standar penyelenggaraan sengketa secara elektronik belum disepakati dalam forum perdagangan dunia, namun dalam prakteknya setiap sengketa perdagangan harus diupayakan terlebih dahulu upaya perdamaian para pihak. Dalam konteks penyelenggaraan catatan nama domain di Internet, ICANN telah membuat Uniform Dispute Resolution Policy. Langkah tersebut juga telah diikuti oleh Penyelenggara Nama Domain DOT-ID yang memberikan peluang keberatan dan penyelesaian sengketa dalam konteks pendaftaran nama domain yang bersifat melanggara HKI orang lain, yang umumnya terjadi dalam konteks B2B.

Selain konteks pendaftaran nama domain, maka transaki B2B juga perlu mendapatkan wadah penyelesaian secara online, hal yang paling mudah adalah dengan memberikan kemungkinan penyelesaian mediasi secara online. Hal tersebut sesungguhnya dapat diselenggarakan oleh para mediator dan lawyer. Terhadap standar kemampuan dan penyelenggaraannya dapat ditentukan oleh instansi teknis yang terkait.

Dicermati lebih jauh, sesungguhnya sengketa e-commerce lebih daripada itu, karena ia juga akan mencakup sengketa pelaku usaha dengan konsumen. Dalam konteks ini, seharusnya pemerintah cq Badan Penyelesaian Sengketa Konsumen diharapkan dapat lebih dinamis untuk dapat menyediakan sarana penyelesaian sengketa secara online terhadap transaksi secara online.

\section{Deposit Dokumen Publik untuk Perdagangan Lintas Negara}

Seiring dengan berkembangnya Hague Agreement 1961 yang kini tengah menjalankan electronic apostille, maka dalam konteks transaksi elektronik lintas negara, sesungguhnya guna mendukung keotentikan identitas subyek hukum dan juga dokumen publik, diperlukan adanya kebijakan nasional tentang pengaturan T3P yang menjadi penyelenggara jasa keterpercayaan dan keautentikan itu. Dalam kontek perdata nasional hal tersebut dapat dilakukan dengan memberdayakan fungsi dan peran Kementrian Hukum dan HAM (sebagai competent authorities tukar menukar alat bukti dokumen autentk elektronik) serta Notaris yang dapat 
berperan untuk melakukan legalisasi ataupun sertifikasi terhadap suatu dokumen publik.

\section{Pemberdayaan Profesi Penunjang dan Trust Mark}

Sesuai dengan semangat perdagangan yang lebih condong untuk menghidupkan self-regulatory, maka pada dasarnya peranan pemerintah dapat didukung oleh peranan profesi penunjang TIK sebagai pihak-pihak yang menjamin bahwa informasi berikut sistem penyelenggaraan suatu sistem elektronik adalah sesuai hukum. Hal tersebut dapat dipersepsikan sebagaimana layaknya fungsi profesi penunjang pasar modal dalam memastikan bahwa informasi pada prospektus adalah informasi yang valid. Penulis melihat bahwa setiap profesi penunjang dapat memberikan sertifikasi kelaikan secara sendiri maupun secara kolektif sebagai lembaga penyelenggara sertifikasi keandalan.

\section{Pembinaan dan Pengawasan}

Sehubungan dengan adanya keterkaitan antara Kementrian Perdagangan dengan instansi lain terkait, maka pada dasarnya sanksi administratif dapat dilakukan bersama dengan instansi terkait tersebut. Sebagai contohnya adalah sebelum pemberian izin PPSE, maka PSTE yang bersangkutan harus mendaftarkan terlebih dahulu keberadaan sistemnya pada Kemkominfo. Terlebih dari itu pemerintah berhak untuk mendorong penggunaan nama domain Dot ID dalam PPSE di Indonesia.

Selain mekanisme perizinan, pemerintah juga berhak untuk melakukan pembuatan daftar hitam atas sistem dan pelaku usaha yang berniat buruk atau berperilaku buruk karena tidak mengindahkan kepentingan ekonomi nasional. Hal tersebut dapat berujung kepada tindakan reprositas ataupun retaliasi terhadap negara yang bersangkutan.

\section{Penutup}

\section{Kesimpulan}

Berdasarkan apa yang telah disampaikan di atas, maka dapat ditarik kesimpulan sebagai berikut.

1) Evolusi kebijakan e-commerce telah memperlihatkan adanya tuntutan keberpihakan kepada konsumen dimana pemerintah diharapkan tidak abai atau dapat menjalankan kewenangannya dalam menciptakan iklim persaingan usaha yang sehat dan mencegah segala sesuatu yang dapat mengancam perlindungan hak konsumen. Terhadap perlindungan konsumen, diperlukan suatu ketentuan yang bersifat lentur agar keberadaannya akan senantiasa dapat selaras dengan business model yang dikembangkan secara berkelanjutan oleh Para Pelaku Usaha. 
2) Dalam mengembangan kebijakan e-commerce nasional dan regional, Indonesia harus memperhatikan beberapa standar untuk interoperabilitas transaksi, agar terjadinya hubungan dagang yang fair dengan negara lain dan juga kawasan. Indonesia harus dapat melindungi segenap kepentingan privacy warga negaranya dan kepentingan ekonomi nasionalnya. Indonesia perlu mengatur tentang kemungkinan tumbuhnya industri data center dan juga penyelenggaraan jasa cloud computing serta kaedah pemanfaatan big data oleh para pelaku usaha.

\section{Saran}

Mencermati semua perkembangan yang terjadi, maka penulis dapat menyampaikan rekomendasi sebagai berikut;

1) Dalam rangka mengakomodir kepentingan global dan menjaga kepentingan ekonomi nasional perlukan segera peraturan menteri untuk melakukan pendaftaran dan sertifikasi kelaikan terhadap sistem elektronik. Hal tersebut sebaiknya dilakukan dengan model kualifikasi sehingga tidak menutup pintu bagi pihak asing yang ingin melakukan pendaftaran di Indonesia.

2) Perlunya RPP e-commerce yang bersifat komplenter dari PP PSTE agar perdagangan secara elektronik dapat menjadi sarana kemakmuran atau kesejahteraan rakyat. 


\section{Daftar Pustaka}

Alinea ke-4 Pembukaan UUD Negara RI.

"Ditjen Pajak Sikapi Perkembangan E-Commerce Dengan Bijak", <http://www.pajak.go.id/content/ditjen-pajak-sikapi-perkembangan-ecommerce-dengan-bijak>, diakses tanggal 18 mei 2013.

Undang-undang No. 6/1983, diganti dengan Undang-undang no.16/2000 tentang Undang-undang Ketentuan Umum dan Tatacara Perpajakan.

Undang-undang No.7/1983, diubah dengan Undang-undang No. 17/2000 tentang Undang-undang Pajak Penghasilan.

Undang-undang No. 8/1983, diubah dengan Undang-undang No. 18/2000; Undang-undang Pajak Bumi dan Bangunan - UU PBB Undang-undang No. 12/1985 diubah dengan Undang-undang No. 12/1994 tentang Pajak Pertambahan Nilai atas Barang dan Jasa dan Pajak Penjualan atas Barang Mewah.

Undang-undang No. 19/1997, diubah dengan Undang-undang No. 19/2000 tentang Undang-undang Penagihan Pajak dengan Surat Paksa.

Undang-undang No. 21/1997 diubah dengan Undang-undang No. 20/2000 tentang Undang-undang Bea Perolehan Hak atas Tanah dan Bangunan.

Undang-undang No. 14 tahun 2002 tentang Pengadilan Pajak .

Undang-undang No. 13 of 1985 tentang Bea Meterai. 